\title{
Geo(Im)pulse
}

\section{Caprovis savinii (Bovidae, Mammalia) rediscovered: horn core finds of an Early Pleistocene antelope from the North Sea floor}

\section{B. De Wilde}

Bochtenstraat 47, 9270 Laarne, Belgium. Email: bjorn.dewilde@pandora.be

Manuscript received: March 2006; accepted: August 2006

\section{Abstract}

For more than 120 years since the name Caprovis savinii was founded on the basis of a bovid horn core from the 'Forest Bed' at Overstrand (Norfolk, UK), only one other find has been assigned to this species. Recently, two horn cores and one horn core fragment of the species have been discovered at two sand and gravel sorting centres in the Netherlands. The bone-bearing sediments are exposed on the North Sea floor, just off the coast of Great Yarmouth (Norfolk, UK). By comparing fossil and extant taxa, a classification within the bovid tribe Antilopini is proposed. Based on the accompanying fauna from the specific dredging area and the litho- and chronostratigraphy at Overstrand, C. savinii is placed within the Early Pleistocene.

Keywords: bovid, dredging, Forest Bed, Yarmouth Roads Formation

\section{Introduction}

Newton (1882) founded the species Caprovis savinii on the basis of a single right horn core with part of the frontal bone, obtained from the 'Forest Bed' at Overstrand (Norfolk, UK). The horn core was in the collection of Mr. A.C. Savin, of which a large part is now stored in the Natural History Museum, London. It took nearly 90 years before another specimen was assigned to this species. Spencer (1970) mentions briefly his discovery of a rolled left horn core of Caprovis savinii in a box full of broken bones collected by Mr. J.E. Sainty of West Runton. The specimen is now in the collections of the Ipswich Museum (Suffolk, UK; IPSMG: R1939-222).

Collecting at two sand and gravel sorting centres in the Netherlands has recently yielded three horn cores of which the characteristics point to Caprovis savinii.

\section{Provenance and geological setting}

An important commercial dredging area for sand and gravel is situated off the coast of Great Yarmouth (Norfolk, UK; Fig. 1). Several companies are active there, each of them exploiting

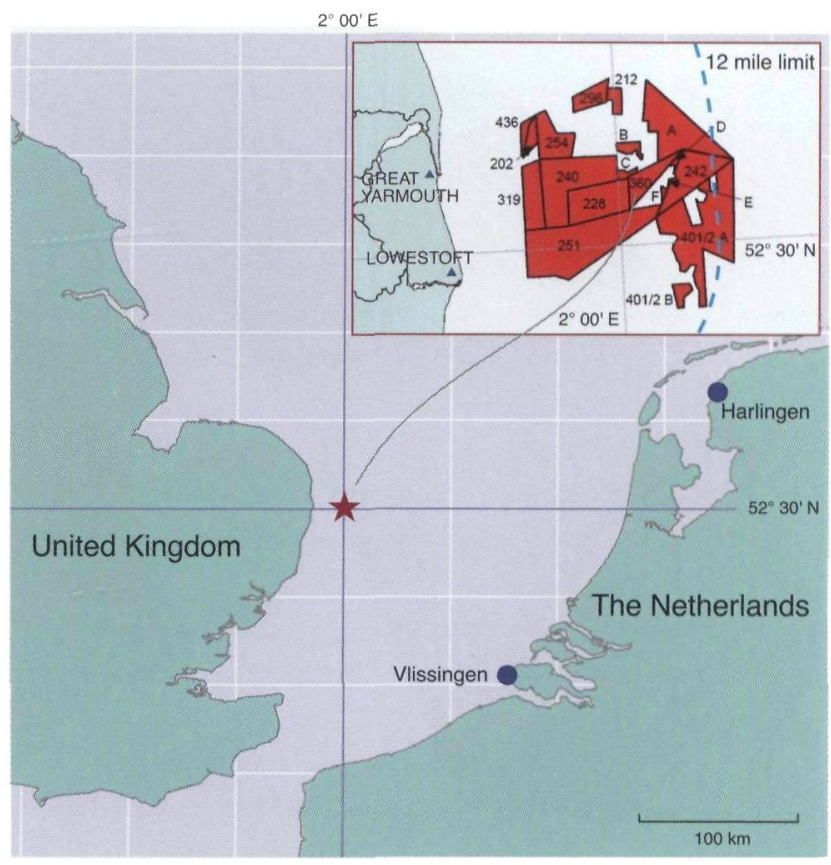

Fig. 1. Location of the source area of the three Caprovis savinii horn cores (asterisk) and of the sorting centres onshore (full circle). Detail showing the different dredging areas. 
one or more smaller areas where no other companies are allowed. The raw materials are transported to sorting centres onshore, to be used in the construction industry. Principal landing sites are located on the English east coast and on the west coast of the Netherlands. As most of the exploited deposits are of Pleistocene age, the sorting centres are appropriate venues to collect Pleistocene mammalian remains.

Two horn cores were discovered at the sorting centre SBV (Sorteerbedrijf Vlissingen) in Vlissingen and one was collected at the sorting centre of Spaansen in Harlingen, both located in the Netherlands (Fig. 1). The latter was dredged from area $360\left(52^{\circ} 33^{\prime} \mathrm{N}, 02^{\circ} 01^{\prime} \mathrm{E}\right)$, at a sea depth of approximately $20 \mathrm{~m}$. Specific provenance information on the SBV specimens is not available, because material from several dredging areas off Great Yarmouth is delivered there.

According to the geological map (Cameron et al., 1984), the worked deposits are part of the Yarmouth Roads Formation, an unit of sand with clay and gravel layers up to 70 metres thick. The gravels are composed of flint and quartzite pebbles and usually occur in thin layers. Mudstone pebbles and gravelsized shell debris also occur (Harrison, 1988), as do peat and wood clasts (Cameron et al., 1992). The nature and distribution of the sediments in the Yarmouth Roads Formation suggest deposition in a large delta complex, commonly referred to as the Ur-Frisia or Eridanos, draining a large part of Northwestern Europe during Early and early Middle Pleistocene times (Cameron et al., 1992).

\section{Description and identification}

One of the three recently discovered horn cores consists of a basal fragment while two are fairly complete (Fig. 2, Fig. 3). All three are in the collection of the National Museum of Natural History (Naturalis) in Leiden, the Netherlands. The most complete specimen was collected at the sorting centre SBV in 2004 by Mr. Theo Lambrechts and has collection number St. 450761. The basal fragment with part of the frontal has also been discovered at SBV, by Mr. Kees Van Hooijdonk in 2001 and bears collection number St. 450766. The third specimen, with collection number St. 450765, was discovered in 2003 by Mr. Lieuwe Talstra and Mr. Joost Snaaijer at the sorting centre of Spaansen.

The SBV specimens have a black to blackish grey colour, which differs clearly from the rusty dark brown of the Spaansen specimen. The latter has also a lesser degree of mineralisation, although all three are heavily mineralised.

Specimen St. 450761 is a nearly complete left horn core, with part of the pedicle, frontal and orbit preserved, which makes it possible to reconstruct a vertical implantation on the skull, with an outward and backward bending. The distal end is broken off. The horn core exhibits a slow anticlockwise torsion. It is important to notice that the term torsion is used here to indicate that the axis of twisting stays within the bone. When the axis becomes tangential or external to the surface of the bone, the horn core is described as spiralled.

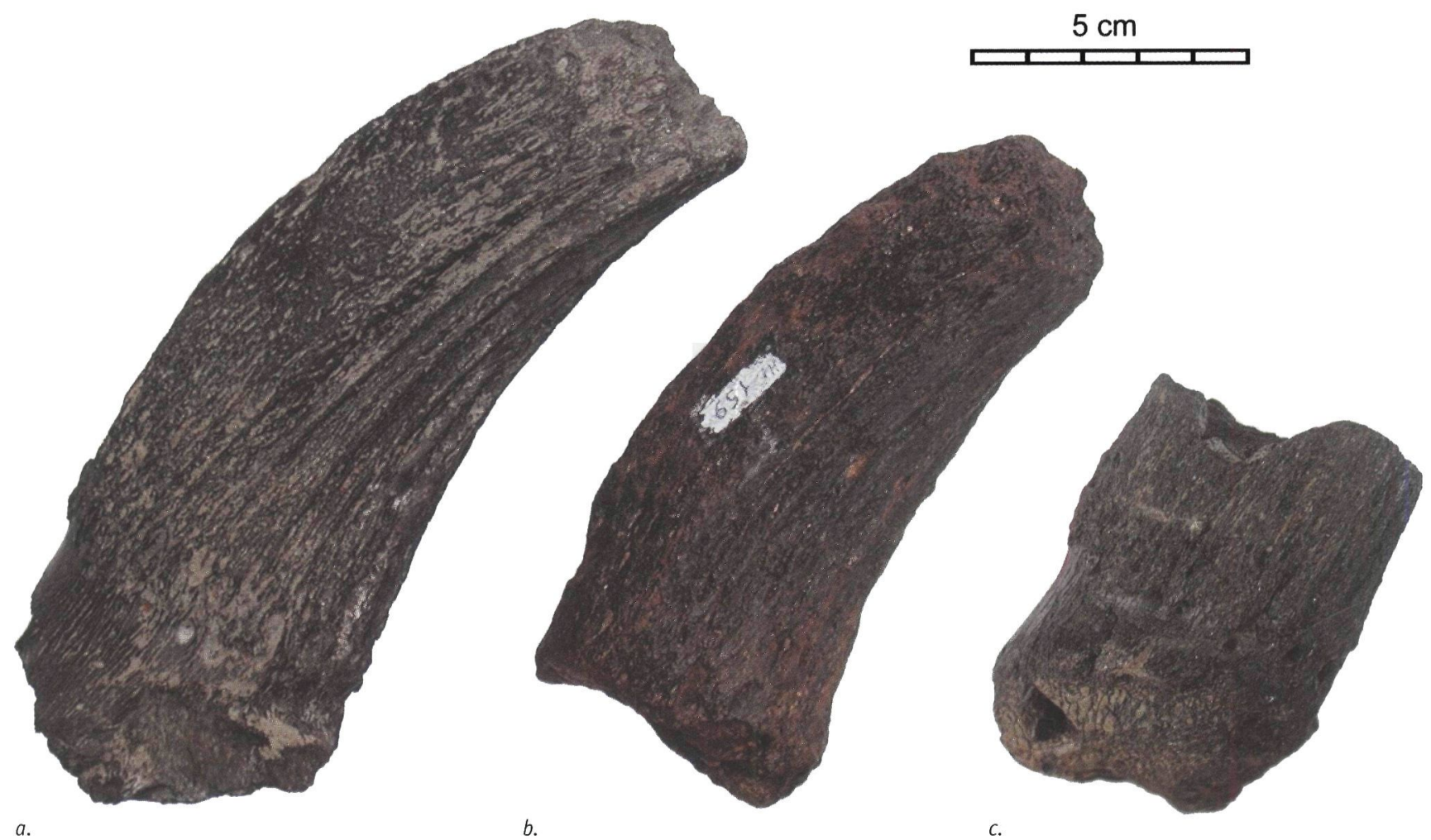

Fig. 2. Horn cores of Caprovis savinii - anterior side; a. left horn core with part of the pedicle, frontal and orbit (St. 450761); b. left horn core (St. 450765); c. basal fragment of a left horn core with part of the pedicle and frontal (St. 450766). 


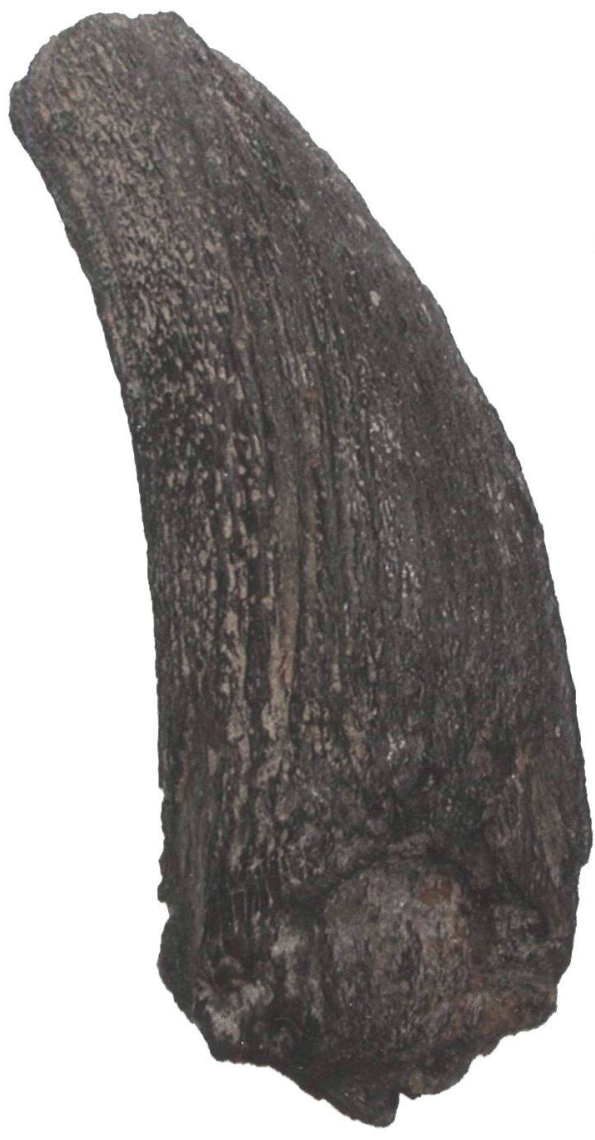

Fig. 3. As in Fig. 2, but posterior side.

The horn core is flattened and has an anterior keel, resulting in a pointed oval in cross-section. The surface is rugged and shows several deep, longitudinal, grooves passing upwards towards the outer edge of the anterior side. The posterior side has three deep grooves, the most anterior one ending at the keel. The pedicle is short and smooth.

Specimen St. 450765 is somewhat smaller and is broken off at its base. It has similar morphological features as St. 450761, nonetheless erosion has led to fading of the grooves.

Specimen St. 450766 has only the basal part of the horn core preserved, but part of the pedicle and frontal are still present. It is comparable in size to the other specimens, the position of the grooves and foramina at the basal margin being almost identical to the other SBV specimen. Table 1 shows some measurements of the specimens.

The description above leaves no doubt that the three horn cores belong to one and the same bovid species. The robust and anticlockwise torsioned horn cores with an anterior keel and deep longitudinal grooves on both the anterior and posterior side, are characteristic of Caprovis savinii Newton, 1882.
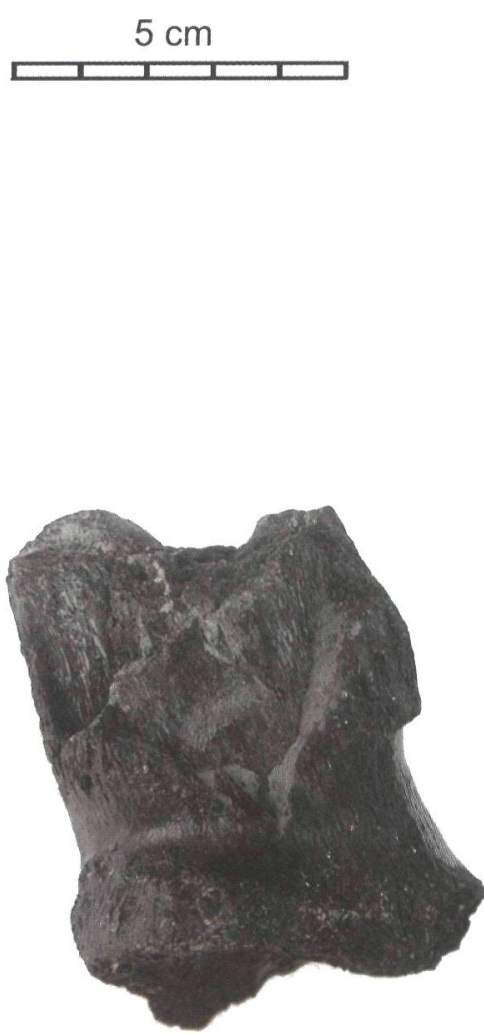

c.
Table 1. Dimensions of the known Caprovis savinii horn cores.

\begin{tabular}{llll}
\hline & $\begin{array}{l}\text { Total length } \\
\text { anterior } \\
\text { curvature (mm) }\end{array}$ & $\begin{array}{l}\text { Max. basal } \\
\text { diameter } \\
(\mathbf{m m})\end{array}$ & $\begin{array}{l}\text { Min. basal } \\
\text { diameter } \\
(\mathrm{mm})\end{array}$ \\
\hline Holotype M6108 & 225 (broken) & 74 & 54 \\
IPSMG: R1939-222 & 150 (broken) & 63 & 45 \\
St. 450761 & 135 (broken) & 66 & ca. 51 (damaged) \\
St. 450765 & 134 (broken) & 59 & 44 \\
St. 450766 & - (basal fragment) 64 & ca. 48 (damaged) \\
\hline
\end{tabular}

\section{Systematic position of Caprovis savinii}

Because of its resemblance to the horn cores of the Sardinian sheep (Caprovis musimon, now Ovis musimon), Newton (1882) decided to place the 'Forest-bed horn core' into the same genus. There are however several clear differences.

Horn cores of the Sardinian sheep curve initially upwards and backwards, then outwards, downwards and a little forwards. They lack grooves and do not exhibit a sharp keel. In fact, no member of the Caprini has horn cores that closely resemble those of Caprovis savinii. Horn cores of the genus Capra do point upwards and sometimes possess a sharp keel, but they 
lack grooves, and torsion only occurs within the markhor (Capra falconeri). Horn cores of the latter, however, lack grooves and possess two keels. Several other members of the Caprini have spiralled horn cores, as the axis of twisting becomes external to the surface of the bone.

A classification within the Ovibovini is not any more acceptable because of their laterally (e.g. Soergelia) to downward (e.g. Ovibos, Praeovibos) pointing dorso-ventrally flattened horn cores (Crégut-Bonnoure \& Guérin, 1996; Schaub, 1951; Harington, 1989). Moreover, Ovibovini lack any significant torsion.

Torsion of the horn cores is a common feature within the Tragelaphini, but also occurs within the Antilopini. The Late Pliocene to Early Pleistocene antelope Pontoceros ambiguus from the Azov Sea and Tiraspol (Ukraine) is characterized by elongated anticlockwise torsioned horn cores with a triangular section at the base, becoming elliptical to the top. There are three rather sharp keels associated with three strong furrows (Verescagin et al., 1971). The Early Pleistocene subspecies $P$. ambiguus mediterraneus from Apollonia and Libakos (Greece) has more massive, less torsioned horn cores with a more elliptical section at their base. The keels are less sharp than those of the type species (Kostopoulos, 1997). Comparing the morphology of the horn cores, it is clear that Caprovis savinii and Pontoceros ambiguus are distinct taxa.

Concerning recent and fossil forms, the biggest resemblances in size and morphology are probably found in ?Antilospira robusta described by Teilhard de Chardin \& Trassaert (1938) from the Villafranchian of Southeastern Shansi (China). In the latter species, the anterior keel is more pronounced, as it 'expands as a wing at the base of the horn'.

Until new and more complete or diagnostic finds become available, a classification of Caprovis savinii within the Antilopini seems most reasonable.

\section{Accompanying mammalian fauna}

Thanks to the cooperation of the management and the employees at SBV and Spaansen, it has been possible to establish a collection of several thousand fossil mammalian remains dredged off Great Yarmouth. The material from SBV is dispersed through several private collections. A well-defined source area is not available, because the dredging company is active in various areas. Most SBV specimens comprise molars and molar fragments and to a lesser degree other skeletal remains of elephantids. Although rather heavily mineralised, the morphometrics of most molars are indicative of woolly mammoth Mammuthus primigenius. Usually, remains of woolly mammoth from the North Sea have a low density and a weak mineralisation (Mol et al., 1999). Molar fragments of the ancestral mammoth $M$. meridionalis and the straight-tusked elephant Palaeoloxodon antiquus are rarely encountered among the SBV material. Besides remains of elephantids, several antler fragments are known, some of them showing diagnostic features of Eucladoceros ctenoides.

Contrary to the SBV material, the Spaansen collection has been brought together by only two people and originates from one specific dredging area (number 360, see Fig. 1). The collectors have a regular appointment with the employees of the sorting centre to put aside the mammalian remains within the large fraction before they enter the breaker. Since the start of the cooperation, several hundred skeletal remains have been collected. Most of them are very fragmentary and show recent fractures, related to the collection method (suction dredging). With few exceptions, all of the remains have the same, high degree of mineralisation. Adhering ferruginous sand and gravel is often present, sometimes with encrusted shell debris. Fragments of molars and bones of $M$. meridionalis and antler fragments of Eucladoceros ctenoides make up more than half of the collected material. Some molar fragments have thinner enamel and a higher lamellar frequency and are attributable to the steppe mammoth $M$. trogontherii or to an advanced $M$. meridionalis. The identification of the cervid material is based on a few diagnostic antler fragments. Besides E. ctenoides, the only other cervid present is an Alces sp. Only one basal antler fragment and two skull fragments with pedicles are available, making a specific identification impossible. A few jugal teeth and several postcranials indicate the presence of a large and robust equid. The scarcity of the material and the lack of complete specimens such as metatarsals and metacarpals make it impossible to obtain a subgeneric distinction. Moreover, the taxonomy of non-caballine equids is anything but straightforward. The dimensions of the bones agree well with those from the Oosterschelde (Netherlands), Het Gat (a deep trench approximately 50 nautical miles off the Dutch coast), East Runton (UK) and Chagny (France) (Mol et al., 2003; Eisenmann, 2003). Furthermore, the collection contains some rhinoceros remains, none of them showing diagnostic features. The only carnivore in the collection is a rather large Ursus sp., represented by a fragmentary left hemimandible with the root of the canine, the alveoli of the two first premolars and the alveoli of the two first molars visible. The fragmentary state of the specimen and the lack of jugal teeth hamper a specific identification.

\section{Biostratigraphy}

Except for the few molar fragments assigned to $M$. trogontherii or to an advanced $M$. meridionalis, it appears that the collection from dredging area 360 does not contain mammalian species of different time periods. This implies that the skeletal remains originate from a relatively thin packet of sediment, which, as stated above, is part of the Early to early Middle Pleistocene Yarmouth Roads Formation. The encountered species are indicative for the Early Pleistocene. E. ctenoides is confined to the Late Pliocene and Early Pleistocene. Typical early Middle 
Pleistocene cervids such as Megaloceros dawkinsi and M. savini have not been recognised in the collection. During the Late Pliocene the mastodont Anancus arvernensis was still present in Northwestern Europe (Mol et al., 1999), but so far none of its remains have been recorded from dredging area 360.

According to Newton (1882), the holotype of Caprovis savinii was obtained from the 'Forest Bed' at Overstrand, Norfolk. It is not clear whether it was found in situ or loose on the beach. On the foreshore of the Cromer to Overstrand area, Reid (1890) described an abundance of bones in a bed of ferruginous conglomerate with clay pebbles, lignite and cakes of peat, resting on the eroded surface of the 'Weybourne Crag'. He also mentioned that Mr. Savin collected from this site. Reid included the bone-bearing bed in his 'Forest-bed (estuarine)'. By pollen analysis, West (1980) was able to assign it to the Pastonian stage, which is part of the Early Pleistocene. Early Middle Pleistocene deposits occurring in the cliffs. No doubt Savin also collected many specimens from cliff falls (Lister, 1996).

Considering the Early Pleistocene age of the collection from dredging area 360 and the chronostratigraphy at the discovery site of the holotype, I propose an Early Pleistocene age for Caprovis savinii. At this moment a more precise dating is not appropriate.

\section{Acknowledgements}

I would like to thank Lieuwe Talstra, Joost Snaaijer, Theo Lambrechts and Kees Van Hooijdonk for giving me the opportunity to study the fossil remains in their collection. They are also greatly thanked for donating their Caprovis horn core to Naturalis. I am very grateful to the management and the employees at SBV and Spaansen for their selfless cooperation. Klaas Post, Dick Mol, Dr John de Vos and Dr Alan Gentry are sincerely acknowledged for discussions on the subject, Machiel Korf for his assistance in preparing the map figure, Dr Evelyne Crégut-Bonnoure and Dr Vadim Titov for providing literature.

\section{References}

Cameron, T.D.J., Laban, C. \& Schüttenhelm, R.T.E., 1984. Flemish Bight: sheet $52^{\circ} \mathrm{N} / 02^{\circ} \mathrm{E}$, Quaternary Geology, $1: 250,000$ series. British Geological Survey and Geological Survey of The Netherlands.

Cameron, T.D.J., Crosby, A., Balson, P.S., Jeffery, D.H., Lott, G.K., Bulat, J. \& Harrison, D.J., 1992. United Kingdom offshore regional report: the geology of the southern North Sea, HMSO for the British Geological Survey.

Crégut-Bonnoure, E. \& Guérin, C., 1996. Ordre des Artiodactyles. Famille des Bovidae. In: Guérin, C. \& Patou-Mathis, M. (eds): Les grands mammifères Plio-Pléistocènes d'Europe. Masson (Paris): 62-106.

Eisenmann, V., 2003. Gigantic horses. In: Petculescu, A. \& Stiuca, E. (eds): Advances in Vertebrate Paleontology 'Hen to Panta' (Papers in Honour of Constantin Radulescu and Petre Mihai Samson). Institute of Speleology (Bucharest): 31-40.
Harington, C.R., 1989. Soergelia: an indicator of holarctic middle Pleistocene deposits? In: Second Annual Muskox Symposium, University of Saskatchewan, 1 - 4 october 1987. National Research Council (0ttawa): A1-A9.

Harrison, D.J., 1988. The marine sand and gravel resources off Great Yarmouth and Southwold, East Anglia. British Geological Survey Technical Report WB/88/9C (Keyworth): $88 \mathrm{pp}$.

Kostopoulos, D.S., 1997. The Plio-Pleistocene artiodactyls (Vertebrata, Mammalia) of Macedonia (N. Greece). 1. The fossiliferous site 'Apollonia-1', Mygdonia basin of Greece. Geodiversitas 19: 845-475.

Lister, A.M., 1996. The stratigraphical interpretation of large mammal remains from the Cromer Forest-bed Formation. In: Turner, C. (ed.): The early Middle Pleistocene in Europe (Proceedings of the SEQS Cromer Symposium, Norwich, United Kingdom, 3 - 7 September 1990). Balkema (Rotterdam): 25-44.

Mol, D., Van den Bergh, G.D. \& de Vos, J., 1999. Fossil proboscideans from the Netherlands, the North Sea and the Oosterschelde Estuary. In: Haynes, G., Klimowocz, J. \& Reumer J.W.F. (eds): Mammoths and the Mammoth Fauna: Studies of an Extinct Ecosystem (Proceedings of the First International Mammoth Conference, St. Petersburg, October 16 - 21, 1995). Deinsea 6: 119-146

Mol, D., Post, K., Reumer, J.W.F., de Vos, J. \& Laban, C., 2003. Het Gat: preliminary note on a Bavelian fauna from the North Sea with possibly two mammoth species. In: Reumer, J.W.F., de Vos, J. \& Mol, D. (eds): Advances in Mammoth Research (Proceedings of the Second International Mammoth Conference, Rotterdam, May 16-20 1999). Deinsea 9: 253-266.

Newton, E.T., 1882. The Vertebrata of the Forest Bed Series of Norfolk and Suffolk. Memoirs of the Geological Survey of the United Kingdom.

Reid, C., 1890. The Pliocene Deposits of Britain. Memoirs of the Geological Survey of the United Kingdom.

Schaub, S., 1951. Soergelia n. gen., ein Caprine aus dem thüringischen Altpleistocaen. Eclogae geologicae Helvetiae 44: 375-381.

Spencer, H.E.P., 1970. A contribution to the geological history of Suffolk. Part 4: The Interglacial Epochs. Suffolk Natural History 15: 148-196.

Teihard de Chardin, P. \& Trassaert, M., 1938. Cavicornia of Southeastern Shansi. Palaeontologia Sinica C 6 (115): 1-106.

Verescagin, N., Alexejeva, L., David, A. \& Baigusheva, V., 1971. Genus Pontoceros. In: Nikiforova, K.V. (ed.): Pleistocene of Tiraspol. Shtiintsa Publishing (Kishinev): 167-170. (in Russian)

West, R.G., 1980. The pre-glacial Pleistocene of the Norfolk and Suffolk coasts. Cambridge University Press (Cambridge): 203 pp. 